\title{
PENGARUH MODEL PEMBELAJARAN KOOPERATIF DAN KEMAMPUAN BERPIKIR LOGIS TERHADAP HASIL BELAJAR KONSTRUKSI BANGUNAN KELAS X SMK NEGERI KABUPATEN DELI SERDANG PROGRAM PASCASARJANA UNIVERSITAS NEGERI MEDAN
}

\author{
Indah Putri Santri / NIDN. 1317099001 \\ STKIP Usman Syarif Kutacane
}

\begin{abstract}
Abstrak
Tujuan penelitian ini adalah Pengaruh Model Pembelajaran Kooperatif Dan Kemampuan Berpikir Logis Terhadap Hasil Belajar Konstruksi Bangunan Kelas X SMK Negeri Kabupaten Deli Serdang Program Pascasarjana Universitas Negeri Medan. Populasi penelitian ini adalah siswa X SMK Negeri I Percut Sei Tuan dan SMK Negeri I Lubuk Pakam Kab. Kabupaten Deli Serdang yang tersebar dalam 6 kelas dan kelas X jurusan Teknik Bangunan X SMK Negeri I Percut Sei Tuan, dan SMK Negeri I Lubuk yang tersebar dalam 4 kelas.40 siswa Kelas X-A dan X-B Program Keahlian Teknik Gambar Bangunan yang dibelajarkan dengan menggunakan model pembelajaran kooperatif tipe STAD dan 40 siswa Kelas X-A dan X-B Program Keahlian Teknik Gambar Bangunan yang dibelajarkan dengan menggunakan model pembelajaran kooperatif tipe NHT. Teknik analisis data adalah Anava dua jalur pada taraf signifikansi $\alpha=0,05$ yang dilanjutkan dengan uji Tukey.Hasil penelitian adalah: (1) rata-rata hasil belajar siswa yang diajar dengan model pembelajaran kooperatif tipe STAD $\bar{X}=23,6$ lebih tinggi dari pada rata-rata hasil belajar siswa yang diajar dengan model pembelajaran kooperatif tipe NHT $\bar{X}=20,87$ dengan $\mathrm{F}_{\text {hitung }}=8,03>\mathrm{F}_{\text {tabel }}=3,97$ (2) rata-rata hasil belajar siswa dengan kemampuan berpikir logis tinggi $\bar{X}=24,15$ lebih tinggi dari pada hasil belajar siswa dengan kemampauan berpikir logis rendah $\bar{X}$ $=23,87$ dengan $F_{\text {hitung }}=15,82>F_{\text {tabel }}=3,97$ (3) terdapat interaksi antara model pembelajaran dan kempuan berpikir logis dalam mempengaruhi hasil belajar konstruksi bangunan dengan $\mathrm{F}_{\text {hitung }}=5,03>\mathrm{F}_{\text {tabel }}=3,97$.
\end{abstract}

\section{Kata Kunci : Model Pembelajaran Kooperatif, Kemampuan Berpikir Logis, Hasil Belajar Konstruksi Bangunan}

\section{PENDAHULUAN}

Pendidikan adalah salah satu bentuk

perwujudan kebudayaan manusia yang

dinamis dan sarat perkembangan. Oleh

Karena itu, perubahan atau perkembangan pendidikan adalah hal yang memang seharusnya terjadi sejalan dengan perubahan budaya kehidupan. Perubahan dalam arti perbaikan pendidikan pada semua tingkat perlu terus menerus dilakukan 
sebagai antisipasi kepentingan masa depan.

Mata pelajaran konstruksi bangunan merupakan mata pelajaran yang terdapat di kurikulum 2013. Adapun pokok-poko materi yang terkandung di dalamnya berupa dasardasar ilmu konstruksi bangunan sederhana mulai dari pengetahuan bahan, metode pelaksanaan pekerjaan konstruksi, utilitas bangunan sederhana dan lain lain. Agar siswa dapat memecahkan soal-soal konstruksi bangunan dipelukan pemahaman, pengetahuan dan keterampilan dalam pembelajaran konstruksi bangunan.

Rata-rata ujianUAS siswa pada tahun 2012-2013, 2013-2014, 2014 2015 belum mencapi nilai Kriteria Konstanta Minimal (KKM) yang ditetapkan untuk mata pelajaran konstruksi bangunan yaitu 75. Hasil belajar siswa seperti Tabel 1.1 siawa SMK N I Percut Sei Tuan dan 1.2 SMK N I Lubuk Pakam

Table 1.1 Nilai Ujian Akhir Semester (UAS) Materi Konstruksi Bangunan Kelas X Program Keahlian Teknik Bangunan SMK N 1 Percut Sei Tuan

\begin{tabular}{|c|c|c|c|}
\hline N & Bidang & Studi \\
o & $\begin{array}{c}\text { Keahli } \\
\text { an }\end{array}$ & Tahun & $\begin{array}{c}\text { Rata- } \\
\text { rata }\end{array}$ \\
\hline
\end{tabular}

\begin{tabular}{|c|c|c|c|}
\hline \multirow{3}{*}{1} & \multirow{3}{*}{$\begin{array}{l}\text { Teknik } \\
\text { Gambar } \\
\text { Bangun } \\
\text { an }\end{array}$} & 2012-2013 & 69,2 \\
\hline & & 2013-2014 & 65,4 \\
\hline & & 2014-2015 & 65,7 \\
\hline \multirow[b]{3}{*}{2} & \multirow{3}{*}{$\begin{array}{l}\text { Teknik } \\
\text { Konstru } \\
\text { ksi } \\
\text { Batu \& } \\
\text { Beton }\end{array}$} & $2012-2013$ & 69,2 \\
\hline & & 2013-2014 & 68,3 \\
\hline & & 2014-2015 & 66,3 \\
\hline \multirow[b]{3}{*}{3} & \multirow{3}{*}{$\begin{array}{l}\text { Tekni } \\
\text { Survei } \\
\text { Dan } \\
\text { Pemeta } \\
\text { an }\end{array}$} & 2012-2013 & 67,1 \\
\hline & & 2013-2014 & 60,3 \\
\hline & & 2014-2015 & 65,2 \\
\hline
\end{tabular}

Table 1.2 Nilai Ujian Akhir Semester (UAS) Materi Konstruksi Bangunan Kelas X Program Keahlian Teknik Bangunan SMK N 1 Lubuk Pakam

\begin{tabular}{|c|l|c|c|}
\hline \multirow{2}{*}{ No } & \multirow{2}{*}{$\begin{array}{c}\text { Bidang } \\
\text { Studi } \\
\text { Keahlian }\end{array}$} & Tahun & $\begin{array}{c}\text { Rata- } \\
\text { rata }\end{array}$ \\
\hline \multirow{2}{*}{1} & $\begin{array}{l}\text { Teknik } \\
\text { Gambar }\end{array}$ & $2012-2013$ & 65,8 \\
\cline { 3 - 4 } & \begin{tabular}{l} 
Gangunan \\
\cline { 3 - 4 } 2
\end{tabular} & $2013-2014$ & 62,3 \\
\hline \multirow{2}{*}{2} & Teknik & $2014-2015$ & 64,4 \\
\cline { 3 - 4 } & Konstruksi & $2012-2013$ & 64,3 \\
\cline { 3 - 4 } & Kayu & $2014-2014$ & 65,1 \\
\hline \multicolumn{3}{|c|}{ Untuk meningkatkan } & 64,4 \\
\hline \multicolumn{2}{|c|}{ hasil }
\end{tabular}

belajar tersebut, maka seorang guru harus mampu memilih dan menentukan model pembelajaran yang sesuai dengan materi pelajaran dan kebutuhan siswa. salah satu solusinya adalah dengan menerapakan model pembelajaran Kooperatif. Pembelajaran kooperatif merupakan suatu model pembelajaran yang saat ini banyak digunakan untuk mewujudkan kegiatan belajar 
mengajar yang terpust pada siswa (student oriented), terutama untuk mengatasi permasalahan yang ditemukan guru dalam mengaktifkan siswa. Model pembelajaran kooperatif yang dapat dikembangkan dalam pembelajarankontruksi bangunan ada beberapa tipe diantaranya adalah model pembelajaran kooperatif tipe Student Teams Achievement Sivision (STAD) dan model pembelajaran kooperatif tipe Numbered Head Together (NHT). Mengacu pada definisi yang dikemukakan oleh Slavin (2008:4) bahwa model pembelajaran kooperatif tipe STAD menempatkan siswa dalam kelompok-belajar beranggotakan empat sampai lima orang yang merupakan campuran menurut tingkat kinerja, jenis kelamin, dan suku. Pembelajaran kooperatif tipe Numbered Head Together (NHT) merupakan tipe yang paling mudah diterapkan pada siswa, terlebih bagi pemula. Model pembelajaran ini memberi penekananpada struktur tertentu yang dirancang khususn untuk mempengaruhui interaksi siswa. dengan kata lain, NHT adalah suatu tipe dari model pembelajaran kooperatif yang dikembangkan untuk melibatkan lebih banyak siswa untuk menelaah materi yang tercakup dalam suatu pelajaran dan mengecek pemahaman mereka terhadap isi pelajaran tersebut sebagai gantinya mengajukan pertanyaan ke seluruh kelas.

\section{PEMBAHASAN}

Belajar merupakan suatu proses usaha yang dilakukan oleh seseorang untuk memperoleh suatu perubahan. Perubahan itu sendiri tampak melalui tingkah laku siswa yang merupakan hasil dari interaksi dengan lingkungannya.Mata pelajaran konstruksi bangunan merupakan mata pelajaran yang terdapat di kurikulum 2013. Konstruksi bangunan diajarkan pada kelas $\mathrm{X}$ baik pada semester ganjil maupun semester genap. Adapun pokok-pokok materi yang terkandung di dalamnya berupa dasar-dasar ilmu konstruksi bangunan sederhana mulai dari pengetahuan bahan, metode pelaksanaan pekerjaan konstruksi, utilitas bangunan sederhana dan lain lain.

Konstruksi Bangunan terdiri dari dua suku kata yaitu konstruksi (construction) yang berarti membangun, sedangkan bangunan yang berarti suatu benda yang dibangun atau didirikan untuk 
kepentingan manusia dengan tujuan, biaya dan waktu tertentu. Konstruksi bangunan berarti suatu cara atau teknik membuat/mendirikan bangunan agar memenuhi syarat kuat, awet, indah, fungsional dan ekonomis.

Hasil belajar konstruksi bangunan merupakan tolak ukur yang digunakan untuk menentukan tingkat keberhasilan siswa dalam mengetahui dan memahami suatu mata pelajaran dalam jurusan Teknik Bangunan, biasanya dinyatakan dengan nilai yang berupa keterampilan, nilai sikap setelah siswa mengalami proses belajar. Melalui proses belajar mengajar diharapkan siswa memperoleh keepandaian dan kecakapan tertentu serta perubahanperubahan pada dirinya.

Rusman (2010:201), model pembelajaran kooperatif merupakan suatu model pembelajaran dimana siswa belajar bekerja sama dalam kelompok-kelompok kecil. Pembelajaran koperatif (cooperative learning) merupakan bentuk pembelajaran dengan cara siswa belajar dan bekerja dalam kelompokkelompok kecil secara kolaboratif yang anggotanya terdiri dari empat sampai enam orang dengan struktur kelompok yang bersifat heterogen. Pada hakikatnya pembelajaran kooperatif sama dengan kerja kelompok. Model pembelajaran Kooperatif Student Team Achieve Division (STAD) dikembangkan oleh Robert Slavin dan teman-temnanya pada tahun 1995 di Universitas John Hopkin. Model ini merupakan salah satu tipe kooperatif yang menekankan aktivitas dan interaksi di antara siswa yanag untuk saling memotivasi dan saling membantu secara maksimal. Model ini merupakan model kooperatif yang paling sederhana.

Dalam model pembelajaran kooperatif tipe STAD guru memberikan suatu pelajaran dan siswa-siswa di dalam kelompok memastikan bahwa semua anggota kelompok mengusai pelajaran tersebut. Akhirnya kuis tentang meteri pelajaran itu diberikan kepada setiap anggota kelompok. Tetapi mereka tidak boleh saling membantu satu sama lain. Penilaian kepada setiap kelompok diberikan berdasarkan penjumlahan nilai-nilai kuis kepada setiap anggota kelompok.

Model pembelajran koperatife tipe NHT merupakan teknik belajar mengajar kepala bernomor yang 
dikembangkan oleh Spencer Kangan pada tahun 1992. Pembelajaran kooperatif ini memberikan kesempatan kepada siswa untuk saling membagikan ide-ide dan mempertimbangkan jawaban yang paling tepat. Meskipun memiliki banyak persamaan dengan pendekatan yang lain, namun pendekatan ini memberi penekananpada penggunaan struktur tertentu yang dirancang untuk mempengaruhi pola interaksi siswa. Model pembelajaran kooperatif tipe NHT merupakan suatu pendekatan yang dikembangkan untuk melibatkan banyak siswa dalam menelaah materi mencakup dalam suatu pembelajaran dan mengecek pemahaman mereka terhadap isi pelajaran tersebut sebagai gantinya mengajukan pertanyaan kepada seluruh kelas.Pada model pembelajaran kooperatif tipe NHT para siswa dibagi kedalam kelompokkelompok kecil dan diarahkan untuk mempelajari materi pelajaran yang telah di tentukan. Tujuan dibentuknya kelompok kooperatif adalah untuk memberikan kesempatan kepada siswa agar dapat terlibat secara aktif dalam proses berpikir dan dalam kegiatan-kegiatan belajar. Dalam hal ini sebagian besar aktivitas pembelajaran berpusat pada siswa, yakni mempelajari materi pelajaran serta berdiskusi untuk memecahkan masalah. Dengan tugas atau maslah yang sama untuk setiap individu dalam kelompok, kemudian siswa bekerja kelompok dan berpikir bersama.

Berpikir merupakan proses bekerjanya akal dalam menelaah sesuatu yang merupakan ciri hakiki dari manusia, dan hasil bekerjanya tidak dapat diketahui oleh orang lain jika dinyatakan dalam bentuk bahasa. Purwanto (1998:43) menjelaskan melalui bahasa manusia dapat memberi nama kepada segala sesuatu yang pernah diamati dan dialami disimpan menjadi tanggapantanggapan dan pengalamanpengalaman kemudian diolahnya melalui berpikir menjadi pengertianpengertian.

Kemampuan berpikir logis yang baik didukung oleh pengguasaan sara berpikir dengan baik pula. Maka dalam proses berpikir logis diharuskan untuk mengetahui dengan benar peranan masing-masing sara berpikir tersebut dalam keseluruhan proses berpikir logis. Berpikir logis menyadarkan diri pada proses metode 
logis baik logika deduktif maupun logika induktif. Ilmu dilihat dari segi pola pikirnya merupakan gabungan antara berpikir deduktif dan induktif.

Kemampuan berpikir logis yang tertinggi adalah tingkat operasi formal, usai siswa sekitar 17 tahun dalam hal ini siswa SMK berada dalam tingkat ini. Pada usia ini, siswa telah memiliki kemampuan berpikir logis dalam memecahkan masalah . siswa yang memiliki kemampuan berpikir logis sampai pada tingkat operasi formal, berarti telah mampu menyelesaikan masalah-masah (soal-soal) yang menantang, ia tidak akan berhenti bekerja sebelum menentukan jalan keluar (jawaban). Dengan demikian maka siswa yang selalu melatih dirinya secara terus menerus akan dapat menemukan proses berpikir logis di dalam memecahkan masalahmasalah pembelajaran. Pada gilirannya siswa akan terbiasa dan testerlatih untuk memecahkan masalah-masalah.

Berdasarkan uraian diatas jelas bahwa kemampuan berpikir logis adalah karakteristik siswa yang berkaitan dengan dengan kemampuan untuk memikirkan cara atau prosedur penyelesaiansoal atau masalah yang dihadapinya secara logis dengan cara mengaitkan apa yang sudah diketahui dengan apa yang akan dipelajari.

\section{METODE PENELITIAN}

Penelitian ini dilaksanakan di SMK Negeri I Percut Sei Tuan Kab.Deli Serdang dan SMK Negeri I Lubuk Pakam Kab. Kabupaten Deli Serdang baik untuk uji coba instrumen maupun pelaksanaan penelitian. Waktu penelitian dilakukan pada semester genap dengan waktu selama empat bulan yaitu awal bulan Desember hingga bulan April pada tahun ajaran 2015/2016.

Populasi dalam penelitian ini adalah seluruh siswa kelas X SMK Negeri I Percut Sei Tuan dan SMK Negeri I Lubuk Pakam Kab. Kabupaten Deli Serdang yang tersebar dalam 6 kelas dan kelas $\mathrm{X}$ jurusan Teknik Bangunan X SMK Negeri I Percut Sei Tuan, dan SMK Negeri I Lubuk yang tersebar dalam 4 kelas.

$$
\text { Sampel penelitian dipilih }
$$
secara acak dengan mengundi 6 kelas di SMK Negeri I Percur Sei Tuan dan 4 kelas SMK Negeri I lubuk Pakam untuk mendapatkan 2 kelas sebagai sampel penelitian. Dari hasil pengundian, terpilih dua kelas sebagai 
kelas yang diajarkan dengan model pembelajaran kooperatif tipe STAD yaitu kelas X-A dan X-B Program Keahlian Teknik Gambar Bangunan berjumlah 48 siswa, namun dari 48 siswa tersebut dipilih kembali menjadi 40 siswa, 20 siswa dari kelas X-A dan 20 siswa dari kelas X-B yang dipilih berdasarkan hasil tes kemampuan berpikir logis (Longeot) yang memiliki kemampuan berpikir logis tinggi dan rendah. Sedanglkan untuk kelas yang diajar dengan model pembelajaran kooperatif tipe NHT SMK Negeri I Lubuk Pakam tepilih Program Keahlian Teknik Gambar Bangunan kelas X-A dan X-B berjumlah 66 siswa, namun dari 66 siswa tersebut dipilih kembali menjadi 40 siswa, 20 siswa dari kelas X-A dan 20 siswa dari kelas X-B, siswa dipilih berdasarkan hasil tes kemampuan berpikir logis (Longeot) yang memiliki kemampuan berpikir logis tinggi dan yang memiliki kemampuan berpikir logis rendah. Sebelum diberikan perlakuan, terlebih dahulu diberikan tes kemampuan berfikir logis, untuk membedakan siswa yang memiliki kemampuan berfikir logis tinggi dan siswa yang memiliki kemampuan berfikir logis rendah.
Teknik analis data yang digunakan adalah teknik statistik deskriptif dan inferensial. Teknik statistik deskriptif digunakan untuk mendeskriptipsikan data antara lain: nilai rata-rata (mean), median, modus, standar deviasi (SD) dan kecenderungan data. Teknik statistik inferensial digunakan untuk menguji hipotesis penelitian, di mana teknik inferensial yang akan digunakan adalah teknik analisis varians Anava dua jalur (desain faktorial 2x2) dengan taraf signifikan 0,05. Sebelumnya Anava dua jalur dilakukan, terlebih dahulu ditentukan persyaratan normalitas menggunkan Uji Lilliefors, sedangkan untuk uji persyaratan homogenitas menggunakan UJi Fisher (F) dan Uji Barlett. UJi Fisher digunakan untuk menguji homogenitas masing-masing kelompok sampel (perlakuan), sedangkan Uji Barlett digunakan untuk menguji homogenitas kelompok sampel (Perlakuan) secara bersama-sama.

Setelah melakukan pengujian persyaratan analisis, selanjutnya dilakukan pengajuan Anava 2 jalur. Jika Anava 2 jalur signifikan, maka diadakan uji lanjur (post hoc test). Uji lanjut dilakukan dengan Uji Scheffe, 
dikarenakan jumlah sampel tiap sel tidak sama (n tidak sama). Jika jemlah sel sampel sama maka uji lanjut dilakukan dengan uji Tukey.

\section{HASIL PENELITIAN}

Berdasarkan hasil analisis data diperoleh bahwa: (1) untuk data kelompok model pembelajaran kooperatif tipe $\operatorname{STAD}\left(\mathrm{A}_{1}\right)$ diperoleh mean sebesar 24,05, (2) untuk data kelompok model Pembelajaran kooperatif tipe NHT $\left(A_{2}\right)$ diperoleh mean sebesar 20,82, (3) untuk data kelompok kemampuan berpikir logis tinggi $\left(\mathrm{B}_{1}\right)$ diperoleh mean sebesar 24,3, (4) untuk data kelompok kemampuan berpikir logis rendah $\left(\mathrm{B}_{2}\right)$ diperoleh mean sebesar 20,47, (5) untuk data kelompok model pembelajaran kooperatif tipe STAD dan kemampuan berpikir logis tinggi $\left(\mathrm{A}_{1} \mathrm{~B}_{1}\right)$ diperoleh mean sebesar 24,1, (6) untuk data kelompok model pembelajaran kooperatif tipe STAD dan kemampuan berpikir logis rendah $\left(A_{1} B_{1}\right)$ diperoleh mean sebesar 20,1, (7) untuk data kelompok model pembelajaran kooperatif tipe NHT dan memiliki kemampuan berpikir logis tinggi $\left(A_{2} B_{1}\right)$ diperoleh mean sebesar 21,3 , (8) untuk data kelompok model pembelajaran kooperatif tipe NHT dan memiliki kemampuan berpikir rendah $\left(A_{2} B_{2}\right)$ diperoleh mean sebesar 20,45. Teknik statistik inferensial dilakukan untuk menguji hipotesis penelitian menggunakan analisis varians dua jalur pada taraf signifikansi $\alpha=0,05$. Analisis varian dalam metode statistik memberikan pengendalian terhadap variabelvariabelluar yang mempengaruhi hubungan antara variabel bebas dan variabel terikat.Berdasarkan hasil analisis varian diperoleh bahwa: (1) data kelompok yang diajar dengan model pembelajaran kooperatif tipe STADlebih tinggi dari pada hasil belajar Konstruksi Bangunan siswa yang diajar dengan model pembelajaran kooperatif tipe NHTdiperoleh $F_{\text {hitung }}$ sebesar 8,03 dan $F_{\text {tabel }}$ sebesar 3,97. Jika dibandingkan nilai $F_{\text {hitung }}$ dengan $\mathrm{F}_{\text {tabel }}$ didapatkan bahwa $\mathrm{F}_{\text {hitung }}>$ $\mathrm{F}_{\text {tabel }}$ dengan taraf signifikansi $(\mathrm{p})=$ 0,05, sehingga pengujian hipotesis menolak Ho dan menerima Ha. Dengan demikian dapat ditarik kesimpulan bahwa hasil belajar Konstruksi Bangunan siswa yang diajar dengan model pembelajaran kooperatif tipe STAD lebih tinggi dibandingkan dengan hasil belajar 
Konstruksi Bangunan siswa yang diajar dengan model pembelajaran kooperatif tipe NHT teruji kebenarannya. (2) data kelompok yang memiliki kemampuan berpikir logis tinggi lebih tinggi dari pada hasil belajar Konstruksi Bangunan siswa dengan kemampuan berpikir logis rendah diperoleh $F_{\text {hitung }}$ sebesar 15,82 dan $F_{\text {tabel }}$ sebesar 3,97. Jika dibandingkan nilai $F_{\text {hitung }}$ dengan $\mathrm{F}_{\text {tabel }}$ didapatkan bahwa $\mathrm{F}_{\text {hitung }}>$ $\mathrm{F}_{\text {tabel }}$ dengan taraf signifikansi $(\mathrm{p})<$ 0,05, sehingga pengujian hipotesis menolak Ho dan menerima Ha. Dengan demikian dapat ditarik kesimpulan bahwa hasil belajar Konstruksi Banguna siswa dengan kemampuan berpikir logis tinggi lebih tinggi dari pada hasil belajar Konstruksi Bangunan siswa dengan kemampuan berpikir logis rendah teruji kebenarannya, dan (3) interaksi antara model pembelajaran kooperatif dan kemampuan berpikir logis dalam memberikan pengaruh terhadap hasil belajar Konstruksi Bangunan siswa diperoleh $F_{\text {hitung }}$ sebesar 13,06dan $\mathrm{F}_{\text {tabel }}$ sebesar 3,97. Jika dibandingkan nilai $\mathrm{F}_{\text {hitung }}$ dengan $\mathrm{F}_{\text {tabel }}$ didapatkan bahwa $F_{\text {hitung }}>F_{\text {tabel }}$ dengan taraf signifikansi $(\mathrm{p})<0,05$, sehingga pengujian hipotesis menolak Ho dan menerima Ha. Dengan demikian dapat ditarik kesimpulan bahwa terdapat interaksi antara model pembelajaran koperatif dan kemampuan berpikir logis dalam memberikan pengaruh terhadap hasil belajar Konstruksi Banguna siswa teruji kebenarannya, dengan jelas dapat dilihat padaGambar 1 berikut ini:

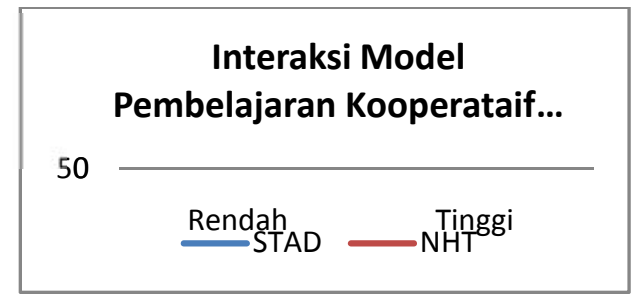

\section{DAFTAR PUSTAKA}

Abdullhak,I. (2001). Komunikasi

Pembelajaran : Pendekatan

Konvergensi Dalam Meningkatkan

Kualitas dan Efektifitas

Pembelajaran.

Bandung:Universitas Pendidikan Indonesia.

Arikunto. S. (2001) Prosedur

Penelitian: Suatu Pendekatan

Praktek. Jakarta : Rineka Cipta

De Bon, E. (1990) Lateral Thingking, Alihbahasa: Budi. Jakarta : Binarupa Aksara.

Purwanto, M.N. (1998). Psikologi

Pendidikan.Bandung : Remaja Rosda Karya

Vol.3 No. 2 Juli- Desember 2018/215 
Riyanto, Yatim, (2009), Pradigdigma

Baru Pembelajaran, Jakarta :

PrenadaMedia Group

Ruman. (2010). Model-Model

Pembelajaran. Bandung: Mulia

Mandiri Press

Rusman.(2011). Model-Model

Pembelajaran: MAengembangkan

Profesionalisme Guru, cetakan ke-

2, Jakarta: Rajagrafindo Persada

Purnawan, Rochadi Arif. (2013)

Upaya Meningkatkan Hasil

Belajar Biologi Melalui Model

Pembelajaran Kooperatif Tipe

Student Teams Achievement

Division (Stad), Jurnal Biosfer,

Volume VII, Nomor 1, Maret

2014, ISSN : 08532451

Sanjaya, Wina. (2010). Strategi

Pembelajaran Berorientasi

Standar Proses Pendidikan.

Jakarta: Kencana

Slameto, (2003), Belajar dan Faktor-

Faktor yang Mempengaruhinya,

Jakarta : Rineka Cipta

Slavin, Robert E. (2008).

Cooperatitive Learning Teori,

Riset, dan Praktik. Bandung :

Nusa Media 